Check for updates

Cite this: RSC Adv., 2018, 8, 40804

\title{
Removal of arsenic(v) from aqueous solutions using sulfur-doped $\mathrm{Fe}_{3} \mathrm{O}_{4}$ nanoparticles $\uparrow$
}

\begin{abstract}
Junhui Liu, ${ }^{a}$ Long Kong, ${ }^{\text {*a }}$ Xueqiong Huang, ${ }^{a}$ Min Liu ${ }^{a}$ and Liang Li (D) *ab
In this study, magnetic sulfur-doped $\mathrm{Fe}_{3} \mathrm{O}_{4}$ nanoparticles ( $\mathrm{Fe}_{3} \mathrm{O}_{4}: \mathrm{S} \mathrm{NPs}$ ) were applied as adsorbents for the removal of $\mathrm{As}(\mathrm{v})$. $\mathrm{Fe}_{3} \mathrm{O}_{4}$ : $\mathrm{S} \mathrm{NPs}$ were fabricated by a two-step route, which included low-temperature mixing and high-temperature sintering. The as-prepared $\mathrm{Fe}_{3} \mathrm{O}_{4}: \mathrm{S} \mathrm{NPs}$ could effectively remove $\mathrm{As}(\mathrm{v})$ under a wide $\mathrm{pH}$ range of 2-10 and presented a high As( $\mathrm{V})$ adsorption capacity of $58.38 \mathrm{mg} \mathrm{g}^{-1}$, which was much better than undoped $\mathrm{Fe}_{3} \mathrm{O}_{4}$ nanoparticles $\left(20.24 \mathrm{mg} \mathrm{g}^{-1}\right.$ ). Adsorption experiments exhibited a pseudo-secondorder model of adsorption kinetics and a Langmuir isotherm model of adsorption isotherms. Additionally, the coexisting ions such as $\mathrm{NO}_{3}{ }^{-}, \mathrm{SO}_{4}{ }^{2-}$, and $\mathrm{CO}_{3}{ }^{2-}$ had no significant effect on $\mathrm{As}(\mathrm{V})$ adsorption and the adsorbent worked well in actual smelting wastewater. XPS and FTIR spectra of $\mathrm{Fe}_{3} \mathrm{O}_{4}: \mathrm{S} N P s$ before and after $\mathrm{As}(\mathrm{v})$ adsorption showed that $\mathrm{Fe}-\mathrm{OH}$ groups played a significant role in the adsorption mechanisms. Moreover, the magnetic $\mathrm{Fe}_{3} \mathrm{O}_{4}: \mathrm{S}$ NPs adsorbents after adsorption could be rapidly separated from wastewater with an external magnetic field. Therefore, $\mathrm{Fe}_{3} \mathrm{O}_{4}: \mathrm{S} N P s$ could be an ideal candidate for the removal of As(v) from water.
\end{abstract}

Received 20th October 2018 Accepted 22nd November 2018

DOI: $10.1039 / \mathrm{c} 8 \mathrm{ra0} 8699 \mathrm{k}$

rsc.li/rsc-advances developed to efficiently remove $\mathrm{As}(\mathrm{v})$ from water in the recent years. ${ }^{21-29}$ As a sort of cheap adsorbents, iron oxides have been used for arsenic removal because of iron's affinity to inorganic arsenic species. ${ }^{30}$ However, in certain situations, iron oxide presents low arsenic adsorption capacity, long adsorption process, and only works in a narrow $\mathrm{pH}$ range, which have greatly limited its application. ${ }^{31,32}$ Hence, specific strategies such as surface modification and elements doping have attracted attentions to conquer these weaknesses.

In this study, sulfur-doped $\mathrm{Fe}_{3} \mathrm{O}_{4}$ nanoparticles $\left(\mathrm{Fe}_{3} \mathrm{O}_{4}: \mathrm{S}\right.$ NPs) with excellent adsorption capacity and separation properties $^{33}$ were used for the removal of As(v) from water. Compared with undoped $\mathrm{Fe}_{3} \mathrm{O}_{4}$ NPs, the sulfur-doped nanoparticles exhibited a widely applicable $\mathrm{pH}$ range of 2-10 for $\mathrm{As}(\mathrm{v})$ removal. The prepared $\mathrm{Fe}_{3} \mathrm{O}_{4}: \mathrm{S}$ NPs were characterized using $\mathrm{X}$-ray diffraction (XRD), transmission electron microscope (TEM), energy dispersive X-ray fluorescence (ED-XRF), Fourier transform infrared (FTIR), vibrating sample magnetometer (VSM), and X-ray photoelectron spectroscopy (XPS) analyses. The adsorption properties of $\mathrm{Fe}_{3} \mathrm{O}_{4}: \mathrm{S}$ NPs were investigated including the effects of initial $\mathrm{pH}$, adsorption kinetics, adsorption isotherms, and the effects of coexisting ions. On account of these results, the possible mechanisms for the removal of As(v) were discussed.

\section{Materials and methods}

\subsection{Materials and preparation}

Sodium arsenate heptahydrate $\left(\mathrm{Na}_{2} \mathrm{HAsO}_{4} \cdot 7 \mathrm{H}_{2} \mathrm{O}\right)$, iron(III) nitrate nonahydrate $\left(\mathrm{Fe}\left(\mathrm{NO}_{3}\right)_{3} \cdot 9 \mathrm{H}_{2} \mathrm{O}\right)$, 1-butylamine, and 
thiourea were supplied by Aladdin Chemical (Shanghai, China). All the chemicals were of analytical reagent grade and were used without any further purification. A $50 \mathrm{mg} \mathrm{L}^{-1} \mathrm{As}(\mathrm{v})$ stock solution was prepared by dissolving $104.12 \mathrm{mg} \mathrm{Na} \mathrm{HAsO}_{4} \cdot 7 \mathrm{H}_{2} \mathrm{O}$ into $500 \mathrm{~mL}$ of distilled water (DI) (>18 $\mathrm{M} \Omega \mathrm{cm})$. As(v) solution was prepared by diluting $\mathrm{As}(\mathrm{v})$ stock solution to a given concentration with distilled water. The industrial wastewater sample was taken from a smelting plant located in Hubei, China.

$\mathrm{Fe}_{3} \mathrm{O}_{4}$ :S NPs were synthesized based on our previous report. ${ }^{33}$ Typically, $60 \mathrm{mmol}$ of thiourea and $20 \mathrm{mmol}$ of $\mathrm{Fe}\left(\mathrm{NO}_{3}\right)_{3}$ were dissolved into $100 \mathrm{~mL}$ 1-butylamine, separately. After ultrasonic dispersion, the two solutions were mixed in a $250 \mathrm{~mL}$ three-neck flask under stirring. The mixture was heated to $60{ }^{\circ} \mathrm{C}$ with continuous stirring for $2 \mathrm{~h}$ in the atmosphere of flowing nitrogen. After cooling it to room temperature, the dark brown colored product was washed with methanol and acetone several times and was dried in a vacuum oven for $1 \mathrm{~h}$ at $60^{\circ} \mathrm{C}$. Then, the product was sintered at $300{ }^{\circ} \mathrm{C}$ for $2 \mathrm{~h}$ in the atmosphere of flowing nitrogen, and it was labeled as $\mathrm{Fe}_{3} \mathrm{O}_{4}$ :S. For comparison, bare $\mathrm{Fe}_{3} \mathrm{O}_{4}$ NPs were prepared following the same procedure without the addition of thiourea. To prove that the $\mathrm{Fe}_{3} \mathrm{O}_{4}$ NPs and $\mathrm{Fe}_{3} \mathrm{O}_{4}$ :S NPs were successfully prepared, XRD spectra and EDX spectra were recorded and provided in ESI (Fig. S2 and S4). $\dagger$

\subsection{Adsorption experiments}

Adsorption experiments were conducted by adding adsorbents into As(v) solutions and stirring them continuously. At certain time intervals, the solutions were sampled and filtered through a $0.22 \mu \mathrm{m}$ membrane to analyze the concentration of As(v). From the obtained results, the effects of initial $\mathrm{pH}$ on $\mathrm{As}(\mathrm{v})$ adsorption, adsorption kinetics, adsorption isotherms, and the effects of competing ions were studied.

The effect of initial solution $\mathrm{pH}$ on $\mathrm{As}(\mathrm{v})$ adsorption was investigated to determine the optimum $\mathrm{pH}$ of $\mathrm{As}(\mathrm{v})$ adsorption. The initial $\mathrm{pH}$ of the solutions was adjusted from 2 to $10 \mathrm{using}$ $0.1 \mathrm{M} \mathrm{HCl}$ and $\mathrm{NaOH}$. The as-prepared adsorbent $(30 \mathrm{mg})$ was added to $60 \mathrm{~mL}$ of As(v) solution $\left(20 \mathrm{mg} \mathrm{L}^{-1}\right)$ under continuous stirring at $30^{\circ} \mathrm{C}$ for $24 \mathrm{~h}$.

Adsorption kinetic experiments were conducted under the following conditions: The initial $\mathrm{pH}$ was set to the obtained optimum value. The as-prepared adsorbent $(50 \mathrm{mg})$ was added to $100 \mathrm{~mL}$ of As(v) solution $\left(20 \mathrm{mg} \mathrm{L}^{-1}\right)$ under continuous stirring at $30{ }^{\circ} \mathrm{C}$ for $24 \mathrm{~h}$. Samples were gathered at certain intervals.

For Adsorption isotherm experiments, the concentrations of As(v) solutions were adjusted ranging from $5 \mathrm{mg} \mathrm{L}^{-1}$ to $50 \mathrm{mg} \mathrm{L} \mathrm{L}^{-1}$. The as-prepared adsorbent $(20 \mathrm{mg})$ was added to $40 \mathrm{~mL}$ of $\mathrm{As}(\mathrm{v})$ solution under continuous stirring at $30{ }^{\circ} \mathrm{C}$. Samples were taken after $24 \mathrm{~h}$.

To investigate the influence of coexisting ions, $20 \mathrm{mg}$ of adsorbent was added to $40 \mathrm{~mL}$ of $\mathrm{As}(\mathrm{v})$ solution $\left(30 \mathrm{mg} \mathrm{L}^{-1}\right)$ containing competing ions of $\mathrm{NO}_{3}{ }^{-}, \mathrm{PO}_{4}{ }^{3-}, \mathrm{SO}_{4}{ }^{2-}$, and $\mathrm{CO}_{3}{ }^{2-}$ under continuous stirring $\left(30^{\circ} \mathrm{C}, 24 \mathrm{~h}\right)$. The concentrations of the competing ions were fixed at $0.4 \mathrm{mM}$ and $0.8 \mathrm{mM}$ to control the molar ratios of competing ions to $\mathrm{As}(\mathrm{v})$ at 1 and 2, respectively. Moreover, a control group was conducted under the same condition in the absence of competing ions.

The industrial wastewater samples (As $0.349 \mathrm{mg} \mathrm{L}^{-1}, \mathrm{Cu}$ $0.095 \mathrm{mg} \mathrm{L}^{-1}$, Ni $0.449 \mathrm{mg} \mathrm{L}^{-1}, 20 \mathrm{~mL}$ ) from a smelting plant were mixed with the as-prepared adsorbent whose dosage range was from $0.25 \mathrm{~g} \mathrm{~L}^{-1}$ to $1 \mathrm{~g} \mathrm{~L}^{-1}$. Under continuous stirring at $30{ }^{\circ} \mathrm{C}$ for $24 \mathrm{~h}$, samples were compared with the original one. Chinese national standard (GB) of arsenic was also utilized as a reference.

The concentrations of As and total iron in the filtrates were analyzed using Inductive Coupled Plasma Emission Spectrometer (ICP-OES 5110, Agilent, USA) and Atomic Adsorption Spectrometer (ControlAA700, Analytik Jena AG, Germany). After adsorption, the adsorbents were separated from the solution by high-speed centrifuge, and then were dried in a vacuum oven at $60{ }^{\circ} \mathrm{C}$ to determine the adsorption mechanisms.

\subsection{Characterization}

The ED-XRF (EDX-720) analysis was conducted to determine the concentrations of $\mathrm{Fe}, \mathrm{O}$, and $\mathrm{S}$ in the resulted $\mathrm{Fe}_{3} \mathrm{O}_{4}$ :S NPs. To analyze the crystalline structures of nanoparticles, the XRD measurement of $\mathrm{Fe}_{3} \mathrm{O}_{4}$ :S adsorbent before and after adsorption was recorded on a Shimadzu XRD-6100 (Japan). Morphologies of the samples before and after adsorption were characterized using a TEM (JEM-2100F operating at $200 \mathrm{kV}$, Japan). FTIR spectra of $\mathrm{Fe}_{3} \mathrm{O}_{4}$ :S NPs before and after adsorption were recorded by a Thermo Nicolet 6700 spectrometer (USA) over the wavelength range of $4000-400 \mathrm{~cm}^{-1}$, using $\mathrm{KBr}$ as a reference. The magnetic measurement was conducted on a PPMS-9T (ECII) of Quantum Design with a magnetic field up to $3 \mathrm{~T}$. To measure the binding energies and atomic ratios, XPS analysis was performed on a Thermo Scientific Escalab 250Xi Photoelectron Spectrometer (USA) with a monochromatic Al Ka radiation source.

\section{Results and discussion}

\subsection{Adsorption performance}

3.1.1 Effect of $\mathbf{p H}$ on $\mathrm{As}(\mathrm{v})$ removal. The influence of initial pH on As(v) removal by $\mathrm{Fe}_{3} \mathrm{O}_{4}$ :S NPs and $\mathrm{Fe}_{3} \mathrm{O}_{4}$ NPs was investigated under the $\mathrm{pH}$ range of 2-10. As shown in Fig. 1, the $\mathrm{As}(\mathrm{v})$ removal efficiency of $\mathrm{Fe}_{3} \mathrm{O}_{4}$ :S NPs was nearly a constant value when the $\mathrm{pH}$ ranged from 2-9, which meant the As(v) adsorption capacity of $\mathrm{Fe}_{3} \mathrm{O}_{4}$ :S NPs was almost not affected by the change of $\mathrm{pH}$. In comparison, the optimum $\mathrm{pH}$ for $\mathrm{Fe}_{3} \mathrm{O}_{4} \mathrm{NPs}$ to remove $\operatorname{As}(\mathrm{v})$ was 2 , and $\operatorname{As}(\mathrm{v})$ removal efficiency decreased sharply when the $\mathrm{pH}$ increased. At a neutral $\mathrm{pH}$, the $\mathrm{As}(\mathrm{v})$ removal efficiency of $\mathrm{Fe}_{3} \mathrm{O}_{4}$ :S NPs was much higher than that of $\mathrm{Fe}_{3} \mathrm{O}_{4}$ NPs. Thus, $\mathrm{Fe}_{3} \mathrm{O}_{4}$ :S NPs can be applied as an adsorbent at a neutral $\mathrm{pH}$ condition without losing the adsorption capacity or sacrificing the stability, herein the $\mathrm{pH}$ was chosen to be 6 for further adsorption experiments.

3.1.2 Adsorption kinetics. Fig. 2(a) shows the adsorption of $\operatorname{As}(\mathrm{v})$ by the as-prepared adsorbents as time dependent. ${ }^{34}$ The adsorption of $\mathrm{As}(\mathrm{v})$ by $\mathrm{Fe}_{3} \mathrm{O}_{4}$ :S NPs was rapid in the first $60 \mathrm{~min}$, 


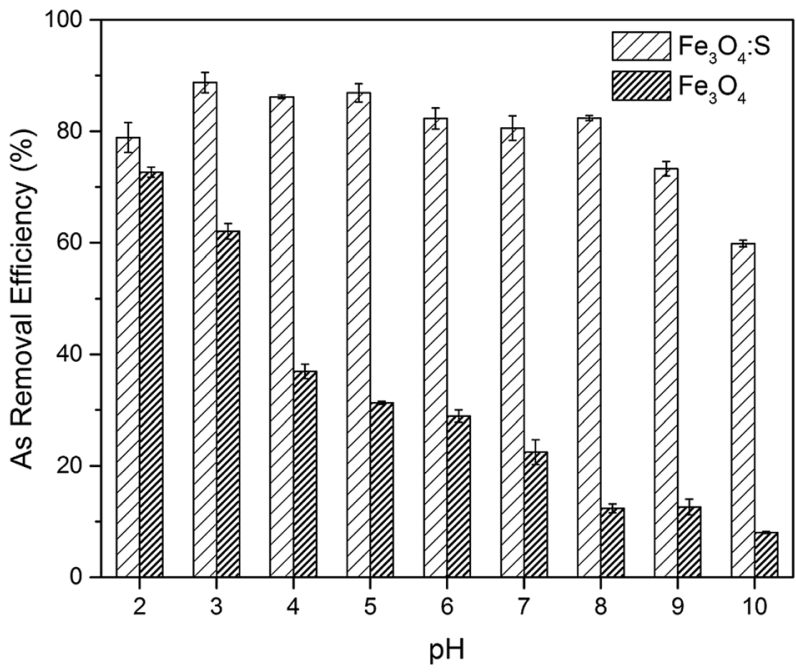

Fig. 1 The $\mathrm{pH}$ dependence for $\mathrm{As}(\mathrm{v})$ adsorption on $\mathrm{Fe}_{3} \mathrm{O}_{4}$ :S NPs and $\mathrm{Fe}_{3} \mathrm{O}_{4} \mathrm{NPs}$. Experimental conditions: initial $\mathrm{As}(\mathrm{V})$ concentration was $20 \mathrm{mg} \mathrm{L}^{-1}(60 \mathrm{~mL})$, adsorbent dosage was $30 \mathrm{mg}, \mathrm{pH} 2-10$, contact time was $24 \mathrm{~h}$, temperature was $30^{\circ} \mathrm{C}$.

and then it slowed down until reached equilibrium after $240 \mathrm{~min}$ with a maximum adsorption capacity of $42.17 \mathrm{mg} \mathrm{g}^{-1}$. In comparison, the $\mathrm{Fe}_{3} \mathrm{O}_{4}$ NPs exhibited a much lower $\mathrm{As}(\mathrm{v})$ adsorption capacity of $19.64 \mathrm{mg} \mathrm{g}^{-1}$. Obviously, the sulfur doping had a significant effect on the As(v) adsorption efficiency of $\mathrm{Fe}_{3} \mathrm{O}_{4}: \mathrm{S}$ NPs. We tested the Fe release kinetics of $\mathrm{Fe}_{3} \mathrm{O}_{4}$ :S NPs and $\mathrm{Fe}_{3} \mathrm{O}_{4}$ NPs in pure water (Fig. 2(b)), and we found that the amount of Fe released from $\mathrm{Fe}_{3} \mathrm{O}_{4}$ :S NPs was much more than that from $\mathrm{Fe}_{3} \mathrm{O}_{4}$ NPs. It was easy to understand, because the $\mathrm{Fe}-$ $\mathrm{S}$ is easier to break than $\mathrm{Fe}-\mathrm{O}$, which could release more $\mathrm{Fe}$ ions in water. However, in the treatment of wastewater containing $\mathrm{As}(\mathrm{v})$ ions, the release of Fe was suppressed as shown in Fig. 2(b) (blue line) because of the fast formation of $\mathrm{Fe}$ arsenates on the surface of adsorbent.

Pseudo-first-order model and pseudo-second-order model, as two different kinds of kinetic models, were utilized to simulate the kinetic experiments data of $\mathrm{Fe}_{3} \mathrm{O}_{4}$ : $\mathrm{S} \mathrm{NPs}$ and $\mathrm{Fe}_{3} \mathrm{O}_{4}$ NPs. The equations are mentioned below: $:^{35,36}$

$$
\begin{gathered}
\ln \left(q_{\mathrm{e}}-q_{t}\right)=\ln q_{\mathrm{e}}-k_{1} t \\
\frac{t}{q_{t}}=\frac{1}{k_{2} q_{\mathrm{e}}^{2}}+\frac{1}{q_{\mathrm{e}}} t
\end{gathered}
$$

where $q_{t}$ and $q_{\mathrm{e}}$ are the amount of As(v) adsorbed at any time $t$ and the equilibrium time $\left(\mathrm{mg} \mathrm{g}^{-1}\right)$, respectively. $k_{1}\left(\mathrm{~min}^{-1}\right)$ and $k_{2}\left(\mathrm{~g} \mathrm{mg}^{-1} \mathrm{~min}^{-1}\right)$ refer to the rate constants of the two fitting models. From the two fitting models, we obtained the adsorption parameters and correlation coefficient $\left(R^{2}\right)$ and listed them in Table 1. For both $\mathrm{Fe}_{3} \mathrm{O}_{4}: \mathrm{S}$ and $\mathrm{Fe}_{3} \mathrm{O}_{4}$ NPs, the plots of $t / q_{t}$ versus $t$ exhibited better linear dependence in the pseudosecond-order model (Fig. 3). As(v) adsorption capacity calculated using pseudo-second-order model was close to the experimental value, suggesting that chemical reaction was the critical rate-determining step. ${ }^{37}$ In our experiments, chemisorption played a significant role in the removal of $\mathrm{As}(\mathrm{v})$ on $\mathrm{Fe}_{3} \mathrm{O}_{4}$ :S NPs and $\mathrm{Fe}_{3} \mathrm{O}_{4}$ NPs.

3.1.3 Adsorption isotherm. Fig. 4(a) shows that the adsorption of $\mathrm{As}(\mathrm{v})$ is concentration dependent. ${ }^{34}$ The plot illustrates the amount of $\operatorname{As}(\mathrm{v})$ adsorbed by the adsorbent $\left(q_{\mathrm{e}}\right)$ versus As(v) equilibrium concentration $\left(C_{\mathrm{e}}\right)$. As shown, $q_{\mathrm{e}}$ increased with the increase in $C_{\mathrm{e}}$ for both samples. Two adsorption isotherm models namely, the Langmuir and Freundlich isotherm models were used to analyze adsorption data of $\mathrm{Fe}_{3} \mathrm{O}_{4}: \mathrm{S}$ NPs and $\mathrm{Fe}_{3} \mathrm{O}_{4}$ NPs, respectively. The fitting equations of two isotherm models can be expressed as follows: $:^{38,39}$

$$
\begin{gathered}
\frac{C_{\mathrm{e}}}{q_{\mathrm{e}}}=\frac{C_{\mathrm{e}}}{q_{\mathrm{m}}}+\frac{1}{q_{\mathrm{m}} K_{\mathrm{L}}} \\
\ln q_{\mathrm{e}}=\ln K_{\mathrm{F}}+\frac{1}{n} \ln C_{\mathrm{e}}
\end{gathered}
$$

where $C_{\mathrm{e}}$ is the $\mathrm{As}(\mathrm{v})$ equilibrium concentration $\left(\mathrm{mg} \mathrm{L}^{-1}\right), q_{\mathrm{e}}$ is the amount of $\mathrm{As}(\mathrm{v})$ adsorbed at equilibrium $\left(\mathrm{mg} \mathrm{g}^{-1}\right), q_{\mathrm{m}}$ is the theoretical maximum adsorption capacity, $K_{\mathrm{L}}$ is the Langmuir constant relating to the energy of $\operatorname{As}(\mathrm{v})$ adsorption. $K_{\mathrm{F}}$ is the
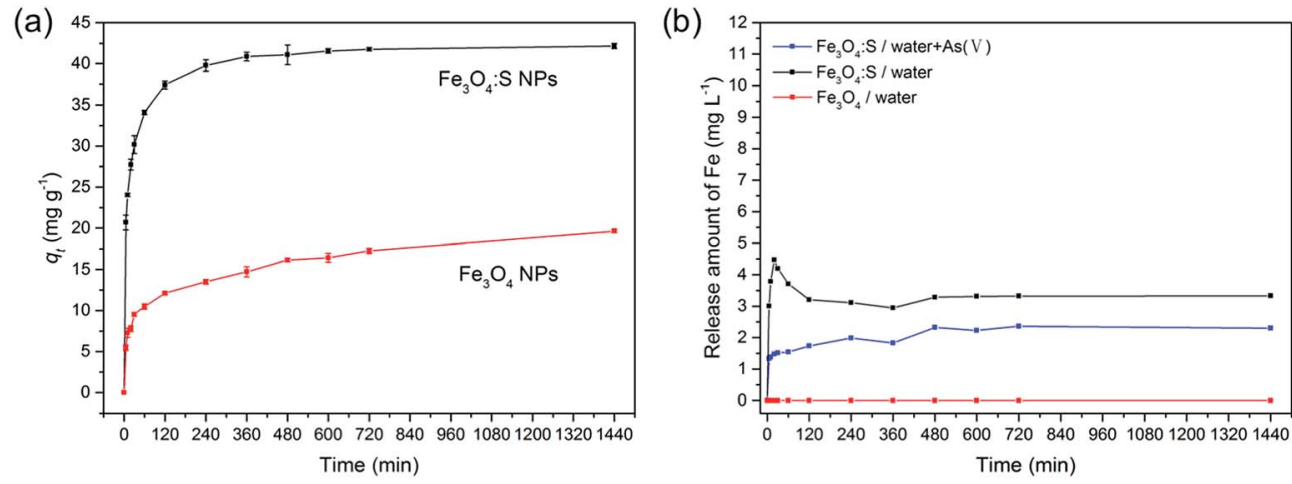

Fig. 2 (a) Adsorption kinetics of $\mathrm{As}(\mathrm{v})$ on $\mathrm{Fe}_{3} \mathrm{O}_{4}: \mathrm{S} N P s$ and $\mathrm{Fe}_{3} \mathrm{O}_{4} \mathrm{NPs}$; (b) Fe releasing kinetics of $\mathrm{Fe}_{3} \mathrm{O}_{4}$ : $\mathrm{S} \mathrm{NPs}$ and $\mathrm{Fe}_{3} \mathrm{O}_{4} \mathrm{NPs}$. Experimental conditions: initial $\mathrm{As}(\mathrm{v})$ concentration was $20 \mathrm{mg} \mathrm{L}^{-1}(100 \mathrm{~mL})$, adsorbent dosage was $50 \mathrm{mg}, \mathrm{pH}$, contact time was $24 \mathrm{~h}$, temperature was $30^{\circ} \mathrm{C}$. 
Table 1 Parameters related to kinetic models for As(v) adsorption

\begin{tabular}{lllr}
\hline Adsorbent & Kinetic model & The rate constant & $q_{\mathrm{e}}\left(\mathrm{mg} \mathrm{g}^{-1}\right)$ \\
\hline $\mathrm{Fe}_{3} \mathrm{O}_{4}: \mathrm{S}$ & Pseudo-first-order model & $5.67 \times 10^{-3}\left(\mathrm{~min}^{-1}\right)$ & 16.08 \\
$\mathrm{Fe}_{3} \mathrm{O}_{4}$ & Pseudo-second-order model & $1.93 \times 10^{-3}\left(\mathrm{~g} \mathrm{mg}^{-1} \mathrm{~min}^{-1}\right)$ & 42.44 \\
& Pseudo-first-order model & $2.44 \times 10^{-3}\left(\mathrm{~min}^{-1}\right)$ & 0.906 \\
& Pseudo-second-order model & $8.35 \times 10^{-4}\left(\mathrm{~g} \mathrm{mg}^{-1} \mathrm{~min}^{-1}\right)$ & 0.999 \\
& & & 12.51 \\
\end{tabular}

theoretical maximum adsorption capacity, and $n$ is related to the Freundlich adsorption intensity parameter. The fitting plots based on Langmuir and Freundlich isotherm models are shown in Fig. 4(b) and (c), and the parameters of Langmuir isotherm model are listed in Table 2. It is clear that the removal of As(v) by $\mathrm{Fe}_{3} \mathrm{O}_{4}$ :S NPs and $\mathrm{Fe}_{3} \mathrm{O}_{4}$ NPs is better simulated by Langmuir model with a higher correlation coefficient $\left(R^{2}\right)$ of 0.990 and 0.935 , respectively. It indicated that the As(v) adsorption was mainly a monolayer sorption on the surfaces of $\mathrm{Fe}_{3} \mathrm{O}_{4}: \mathrm{S}$ and $\mathrm{Fe}_{3} \mathrm{O}_{4}$ NPs. ${ }^{40}$ The theoretical maximum adsorption capacity $\left(q_{\mathrm{m}}\right)$ of $\mathrm{Fe}_{3} \mathrm{O}_{4}$ :S NPs was $58.38 \mathrm{mg} \mathrm{g}^{-1}$, which is much higher than that of $\mathrm{Fe}_{3} \mathrm{O}_{4}$ NPs $\left(20.24 \mathrm{mg} \mathrm{g}^{-1}\right)$.

The feasibility of Langmuir isotherm adsorption can be expressed by separation factor, $R_{\mathrm{L}}$, which is defined by $R_{\mathrm{L}}=1 /(1$ $\left.+K_{\mathrm{L}} C_{0}\right),{ }^{41}$ where $C_{0}$ is the initial concentration of $\mathrm{As}(\mathrm{v})$. The calculated values of $R_{\mathrm{L}}$ in our experiments are 0.171 and 0.435 under the initial concentration of $5 \mathrm{mg} \mathrm{L}^{-1}$, respectively, which are in the range of $0-1$, indicating the type of favorable adsorption. A comparison of maximum adsorption capacity $\left(q_{\mathrm{m}}\right)$ of $\mathrm{As}(\mathrm{v})$ among $\mathrm{Fe}_{3} \mathrm{O}_{4}$ :S NPs and other adsorbents are listed in Table 3.

Compared to $\mathrm{Fe}_{3} \mathrm{O}_{4}$ NPs, the adsorption capacity of $\mathrm{Fe}_{3} \mathrm{O}_{4}: \mathrm{S}$ NPs increased by 2.9 times, which was obvious and might attribute to sulfur doping. Compared to other iron-based adsorbents reported in recent years (Table 3), the distinct increase of adsorption capacity could be beneficial for their application.

3.1.4 Effect of competing ions on As(v) removal. Wastewater is always accompanied with a high salinity and hardness. Coexisting inorganic anions, such as phosphate, may compete with $\operatorname{As}(\mathrm{v})$ for binding sites of the adsorbent and affect As(v) removal. ${ }^{46}$ As shown in Fig. $5, \mathrm{NO}_{3}{ }^{-}$shows no apparent effect on the $\mathrm{As}(\mathrm{v})$ adsorption of $\mathrm{Fe}_{3} \mathrm{O}_{4}: \mathrm{S} \mathrm{NPs}$, on the contrary, $\mathrm{PO}_{4}{ }^{3-}$ had significant inhibition on $\mathrm{As}(\mathrm{v})$ adsorption, while the addition of $\mathrm{SO}_{4}{ }^{2-}$ and $\mathrm{CO}_{3}{ }^{2-}$ decreased the $\mathrm{As}(\mathrm{v})$ adsorption capacity to a certain extent. The influence sequence of the four competing anions on As(v) adsorption is $\mathrm{PO}_{4}{ }^{3-}>\mathrm{SO}_{4}{ }^{2-} \approx \mathrm{CO}_{3}{ }^{2-}>\mathrm{NO}_{3}{ }^{-}$. The decrease of the $\mathrm{As}(\mathrm{v})$ adsorption capacity might be due to the competition for the binding sites between arsenate and phosphate. ${ }^{34}$ These results demonstrated that $\mathrm{Fe}_{3} \mathrm{O}_{4}: \mathrm{S}$ could selectively remove $\mathrm{As}(\mathrm{v})$ in the presence of competing ions, which is a benefit for their practical application.

3.1.5 Removal of arsenic from industrial wastewater. As shown in Fig. 6, the industrial wastewater samples contained As, $\mathrm{Ni}$, and $\mathrm{Cu}$. With the addition of $\mathrm{Fe}_{3} \mathrm{O}_{4}$ :S NPs, it was obvious that not only the concentration of As decreased significantly but also the concentrations of $\mathrm{Ni}$ and $\mathrm{Cu}$. When the dosage of $\mathrm{Fe}_{3} \mathrm{O}_{4}$ :S NPs was $0.25 \mathrm{~g} \mathrm{~L}^{-1}$, the concentration of As in wastewater could reach the standard of $0.1 \mathrm{mg} \mathrm{L}^{-1}$ (Chinese national standard (GB) for secondary copper, aluminum, lead and zink industry, ${ }^{47}$ GB31574-2015) and $0.05 \mathrm{mg} \mathrm{L}^{-1}$ (Environmental quality standards for surface water ${ }^{48} \mathrm{~GB} 3838$-2002). Moreover, $\mathrm{Ni}$ and $\mathrm{Cu}$ could also be adsorbed. $\mathrm{Fe}_{3} \mathrm{O}_{4}$ :S NPs naturally contain two kinds of adsorption sites, i.e. $\mathrm{Fe}^{3+} / \mathrm{Fe}^{2+}$ sites and $\mathrm{S}^{2-}$ sites. The former have excellent affinity to certain anions, such as $\mathrm{AsO}_{3}{ }^{3-}$ and $\mathrm{AsO}_{4}{ }^{3-}$, while the $\mathrm{S}^{2-}$ sites can form strong softsoft interaction (such as $\mathrm{Pb}-\mathrm{S}$ bond and $\mathrm{Cu}-\mathrm{S}$ bond) to remove heavy metal cations. ${ }^{33}$ Thus, principally $\mathrm{Fe}_{3} \mathrm{O}_{4}$ :S NPs could be an effective and promising adsorbent for wastewater treatment particularly for those smelting wastewater which usually contains As and other heavy metal ions.
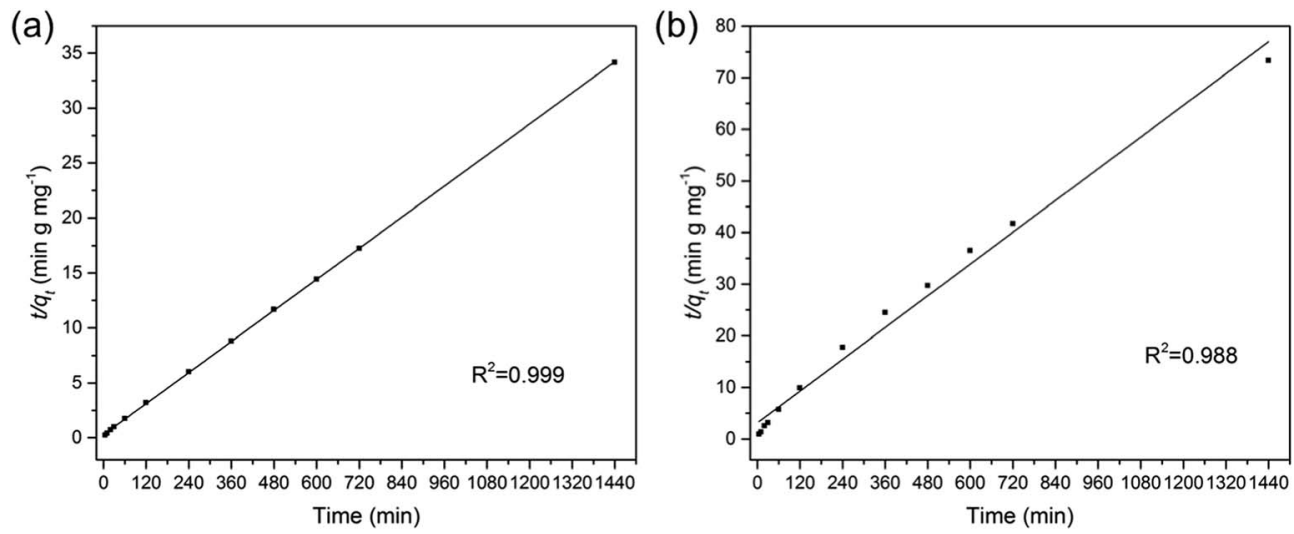

Fig. 3 (a) The pseudo-second-order model for $\mathrm{As}(\mathrm{v})$ adsorption on $\mathrm{Fe}_{3} \mathrm{O}_{4}$ :S NPs; (b) the pseudo-second-order model for As(v) adsorption on $\mathrm{Fe}_{3} \mathrm{O}_{4} \mathrm{NPS}$. 
(a)

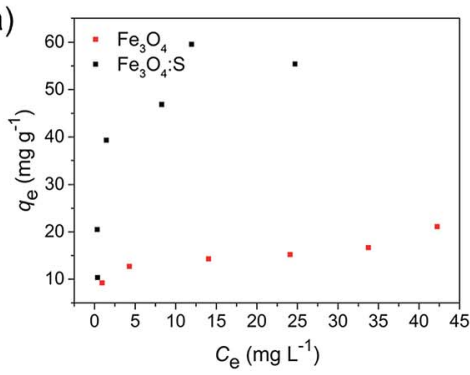

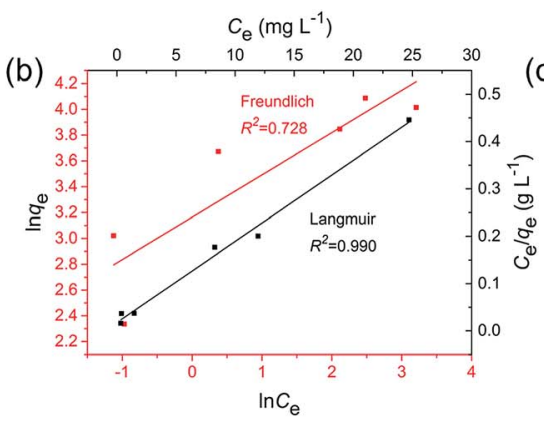

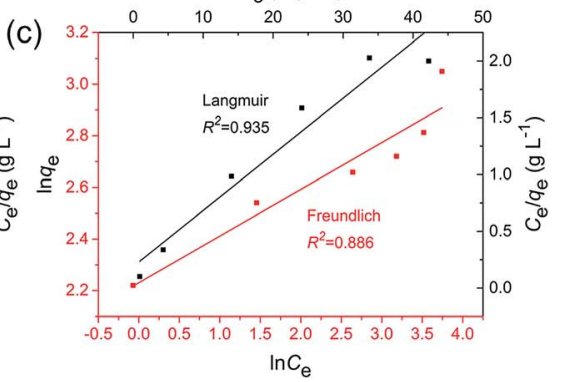

Fig. 4 (a) Adsorption isotherm of $\mathrm{As}(\mathrm{V})$ on $\mathrm{Fe}_{3} \mathrm{O}_{4}: \mathrm{S} \mathrm{NPs}_{3}$ and $\mathrm{Fe}_{3} \mathrm{O}_{4} \mathrm{NPs}$; (b) the fitting of Langmuir and Freundlich models of $\mathrm{Fe}_{3} \mathrm{O}_{4}$ : $\mathrm{S}$ NPs; (c) the fitting of Langmuir and Freundlich models of $\mathrm{Fe}_{3} \mathrm{O}_{4}$ NPs. Experimental conditions: initial concentration was $5-50 \mathrm{mg} \mathrm{L}^{-1}(40 \mathrm{~mL}$ ), adsorbent dosage was $20 \mathrm{mg}, \mathrm{pH} \mathrm{6}$, contact time was $24 \mathrm{~h}$, temperature was $30^{\circ} \mathrm{C}$.

Table 2 Parameters related to Langmuir isotherm model for As(v) adsorption

\begin{tabular}{llll}
\hline Adsorbent & $q_{\mathrm{m}}\left(\mathrm{mg} \mathrm{g}^{-1}\right)$ & $K_{\mathrm{L}}\left(\mathrm{L} \mathrm{mg}^{-1}\right)$ & $R^{2}$ \\
\hline $\mathrm{Fe}_{3} \mathrm{O}_{4}: \mathrm{S}$ & 58.38 & 0.971 & 0.990 \\
$\mathrm{Fe}_{3} \mathrm{O}_{4}$ & 20.24 & 0.260 & 0.935
\end{tabular}

Table 3 Comparison of Langmuir adsorption capacity $\left(q_{m}\right)$ for the adsorption of As(v) by adsorbents

\begin{tabular}{lll}
\hline Adsorbent & $q_{\mathrm{m}}\left(\mathrm{mg} \mathrm{g}^{-1}\right)$ & Ref. \\
\hline Chitosan-functionalized GO & 71.9 & 42 \\
Ascorbic acid-coated $\mathrm{Fe}_{3} \mathrm{O}_{4}$ & 16.56 & 43 \\
$\mathrm{Fe}_{3} \mathrm{O}_{4} @ \mathrm{TiO}_{2}$ & 10.5 & 44 \\
$\mathrm{Fe}_{3} \mathrm{O}_{4}-\mathrm{HBC}$ & 3.35 & 45 \\
$\mathrm{Sulfur}^{-d o p e d ~} \mathrm{Fe}_{3} \mathrm{O}_{4}$ & 58.38 & This work
\end{tabular}

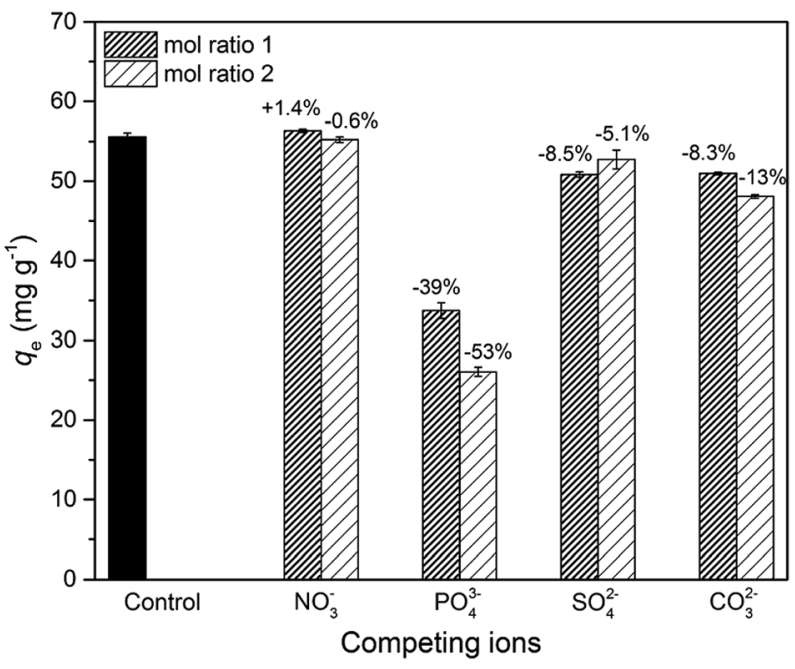

Fig. 5 The effect of competing anions on $\mathrm{As}(\mathrm{v})$ removal by $\mathrm{Fe}_{3} \mathrm{O}_{4}: \mathrm{S}$ NPs. Experimental conditions: initial As(v) concentration was $30 \mathrm{mg} \mathrm{L}^{-1}$ $(40 \mathrm{~mL}$ ), adsorbent dosage was $20 \mathrm{mg}, \mathrm{pH} 6$, contact time was $24 \mathrm{~h}$, temperature was $30^{\circ} \mathrm{C}$.

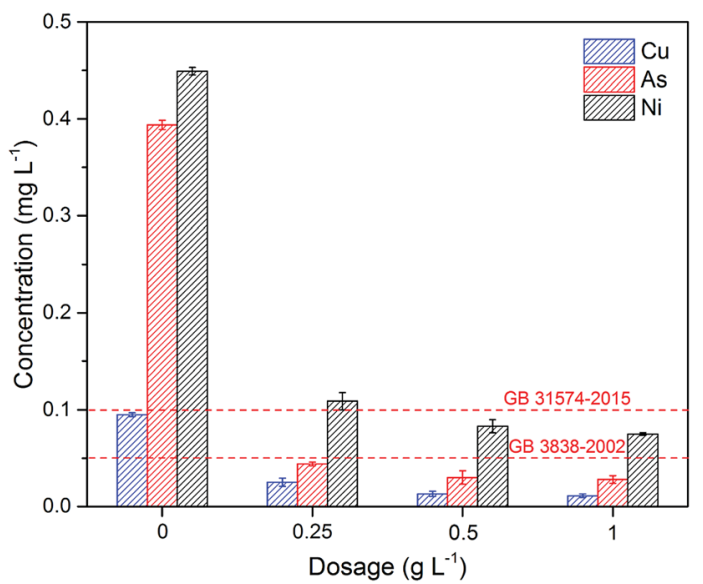

Fig. 6 The removal of $\mathrm{As}, \mathrm{Cu}$, and $\mathrm{Ni}$ by $\mathrm{Fe}_{3} \mathrm{O}_{4}: \mathrm{S}$ NPs in industrial wastewater. Experimental conditions: adsorbent dosage was $0.25-1 \mathrm{~g}$ $\mathrm{L}^{-1}$, contact time was $24 \mathrm{~h}$, temperature was $30^{\circ} \mathrm{C}$ (GB 31574-2015:47 Emission standards of pollutants for secondary copper, aluminum, lead, and zink industry; GB 3838-2002:48 Environmental quality standards for surface water).

\subsection{Adsorption mechanisms}

To elucidate the major adsorption mechanisms of As(v) by $\mathrm{Fe}_{3} \mathrm{O}_{4}: \mathrm{S}$ NPs, XRD and TEM analyses were first conducted. Fig. 7 shows the XRD spectra of $\mathrm{Fe}_{3} \mathrm{O}_{4}: \mathrm{S}$ NPs before and after the As(v) adsorption. The peaks of $\mathrm{Fe}_{3} \mathrm{O}_{4}: \mathrm{S}$ NPs at $30.20^{\circ}, 35.48^{\circ}, 43.32^{\circ}$, $53.74^{\circ}, 57.32^{\circ}$, and $62.78^{\circ}$ correspond to the (220), (311), (400), (422), (511), and (440) lattice planes of magnetite $\mathrm{Fe}_{3} \mathrm{O}_{4}$ (JCPDS 19-0629), respectively, proving that the $\mathrm{Fe}_{3} \mathrm{O}_{4}: \mathrm{S}$ NPs were prepared successfully and were well-crystallized. The characteristic diffraction peaks of $\mathrm{Fe}_{3} \mathrm{O}_{4}: \mathrm{S}$ NPs slightly shifted to a smaller angle compared with $\mathrm{Fe}_{3} \mathrm{O}_{4}$ NPs (Fig. S2 $\dagger$ ). After As(v) adsorption, it is clear that compared with the $\mathrm{Fe}_{3} \mathrm{O}_{4}: \mathrm{S}$ NPS before adsorption, there was neither any shift in characteristic peaks nor a new peak occurred, which meant the wellcrystallized nanoparticles were stable in the As(v) removal process.

The morphologies of $\mathrm{Fe}_{3} \mathrm{O}_{4}: \mathrm{S}$ NPs before and after $\mathrm{As}(\mathrm{v})$ adsorption are shown in Fig. 8. The well-crystallized nanoparticles had a size ranging from $4.34 \mathrm{~nm}$ to $13.46 \mathrm{~nm}$ with an average size of $7.84 \mathrm{~nm}$. We didn't observe obvious changes on 


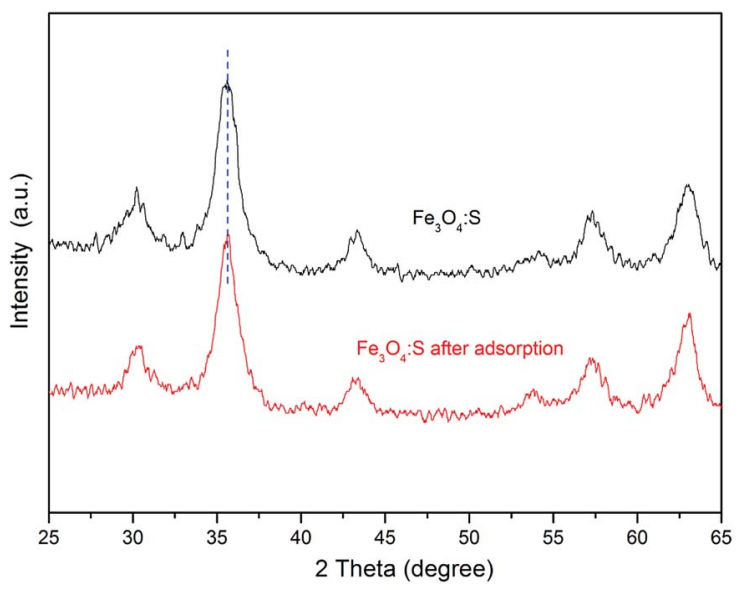

Fig. 7 XRD spectra of $\mathrm{Fe}_{3} \mathrm{O}_{4}$ :S NPs before and after $\mathrm{As}(\mathrm{V})$ adsorption. Experimental conditions: initial As(v) concentration was $50 \mathrm{mg} \mathrm{L}^{-1}(100$ $\mathrm{mL}$ ), adsorbent dosage was $60 \mathrm{mg}, \mathrm{pH} \mathrm{6}$, contact time was $24 \mathrm{~h}$, temperature was $30^{\circ} \mathrm{C}$.

the morphologies and size distribution of these $\mathrm{Fe}_{3} \mathrm{O}_{4}$ :S NPs after adsorption experiments, which is consistent with the XRD pattern. The lattice fringes with a $d$-spacing of $0.248 \mathrm{~nm}$ are assigned to the (311) planes of $\mathrm{Fe}_{3} \mathrm{O}_{4}$, and they remained almost unchanged after As(v) adsorption (Fig. 8(b) and (d)). The above XRD and TEM data indicate that the adsorption of As(v) most likely happened on the surface of $\mathrm{Fe}_{3} \mathrm{O}_{4}$ :S NPs and didn't cause the crystal structure change. Thus, the FTIR analyses were conducted to check the surface changes of $\mathrm{Fe}_{3} \mathrm{O}_{4}$ :S NPs.

The FTIR spectra of $\mathrm{Fe}_{3} \mathrm{O}_{4}$ :S NPs before and after As(v) adsorption are shown in Fig. 9. For the sample before adsorption, it can be seen that the broad peak at wavenumbers $3402 \mathrm{~cm}^{-1}$ represents -OH stretching vibration, and the peak at $1621 \mathrm{~cm}^{-1}$ represents $-\mathrm{OH}$ bending vibration. ${ }^{49}$ They exhibit certain changes at $3420 \mathrm{~cm}^{-1}$ and $1633 \mathrm{~cm}^{-1}$ after $\mathrm{As}(\mathrm{v})$ adsorption, respectively. A strong peak at $1041 \mathrm{~cm}^{-1}$ was observed from the sample before adsorption, which was assigned to the bending vibration of hydroxyl group (Fe$\mathrm{OH}){ }^{50,51}$ and it evidently weakened after adsorption, which might be attributed to the involvement of the $\mathrm{Fe}-\mathrm{OH}$ groups in the adsorption process. The peak at $566 \mathrm{~cm}^{-1}$ represented $\mathrm{Fe}-\mathrm{O}$ vibration. ${ }^{29}$ After As(v) adsorption, it had a small shift at $577 \mathrm{~cm}^{-1}$. In addition, a new peak at $822 \mathrm{~cm}^{-1}$ occurred, which corresponded to the stretching vibration of As-O. ${ }^{51}$ According to these changes in $\mathrm{Fe}_{3} \mathrm{O}_{4}$ :S NPs after $\mathrm{As}(\mathrm{v})$ adsorption, it was confirmed that $\mathrm{As}(\mathrm{v})$ was adsorbed onto the adsorbent and $\mathrm{Fe}-$ $\mathrm{OH}$ played a significant role in the adsorption process. ${ }^{52}$

In addition, we observed the surface structure of $\mathrm{Fe}_{3} \mathrm{O}_{4}$ :S NPs before and after As(v) adsorption by XPS analysis. The XPS spectra of the survey scan and As3d are shown in Fig. 10(a) and (b), respectively. As shown in Fig. 10(a), the detected As species

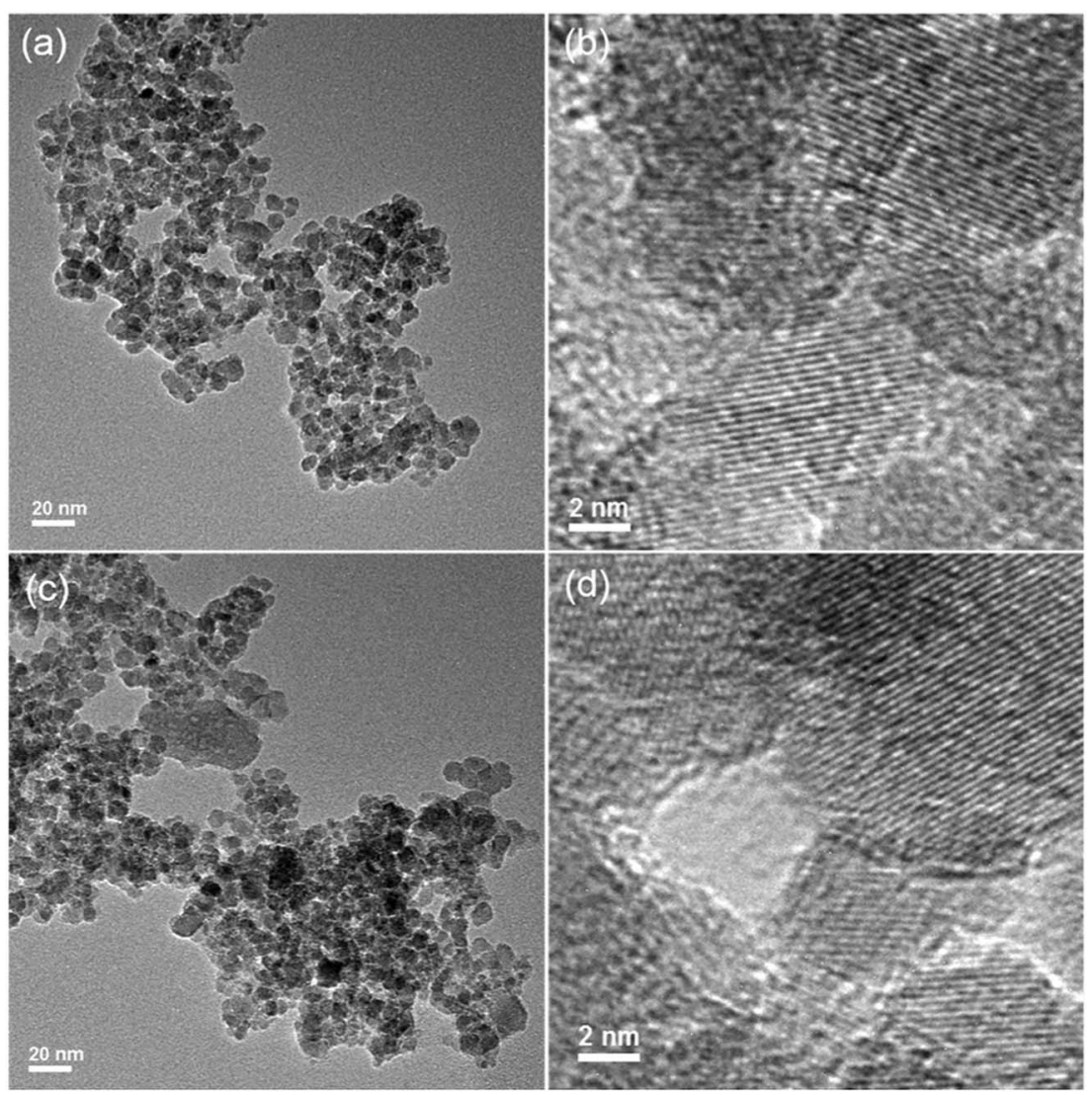

Fig. 8 TEM images of $\mathrm{Fe}_{3} \mathrm{O}_{4}$ :S NPs before and after As(v) adsorption. (a and b) TEM and the corresponding HR-TEM image of Fe $\mathrm{O}_{4}$ :S NPs; (c and d) TEM image and the corresponding HR-TEM image of $\mathrm{Fe}_{3} \mathrm{O}_{4}: \mathrm{S} \mathrm{NPs}$ after adsorption. Experimental conditions were the same as above. 


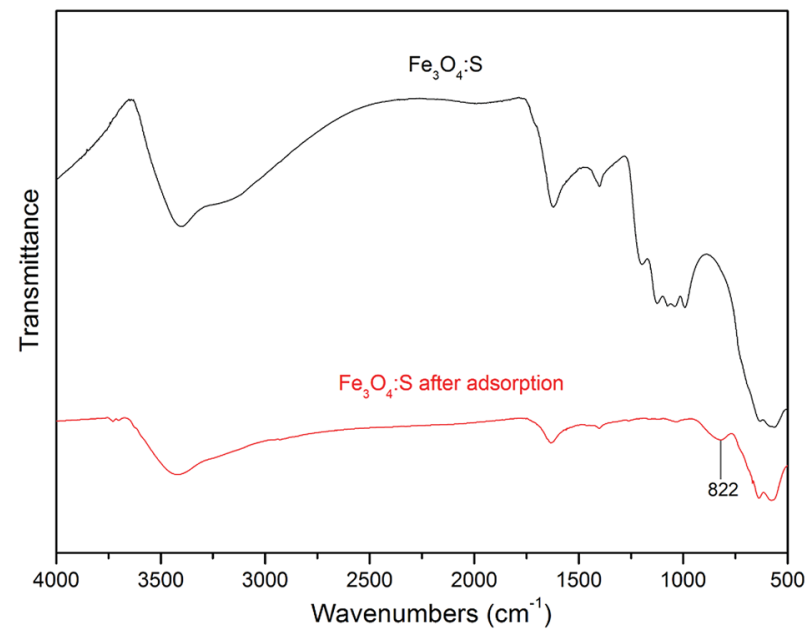

Fig. $9 \mathrm{FTIR}$ spectra of $\mathrm{Fe}_{3} \mathrm{O}_{4}$ :S NPs before and after As(v) adsorption. Experimental conditions were the same as above.

confirms that As was successfully adsorbed on the $\mathrm{Fe}_{3} \mathrm{O}_{4}$ :S NPs. In the high resolution XPS spectra of As3d (Fig. 10(b)), the adsorbed $\mathrm{As}$ on $\mathrm{Fe}_{3} \mathrm{O}_{4}$ :S NPs was mainly assigned to $\mathrm{As}(\mathrm{v})$, since the peak at $45.5 \mathrm{eV}$ for $\mathrm{As}(\mathrm{v})$ is much higher than that at $44.9 \mathrm{eV}$ for As(III). As shown in Fig. 10(a), the peak of S2p nearly disappeared after As(v) adsorption. The weight percentage of $\mathrm{Fe}, \mathrm{O}$, $\mathrm{S}$, and As before and after adsorption measured by XRF are summarized in Table 4. As shown in Table 4, the amount of $\mathrm{S}$ in $\mathrm{Fe}_{3} \mathrm{O}_{4}$ :S NPs after adsorption decreased to a large extent, which was consistent with the XPS spectrum. Considering the abovementioned Fe release and the sulfur decrease in $\mathrm{Fe}_{3} \mathrm{O}_{4}: \mathrm{S}$ NPS after adsorption, we believe that the main role of sulfur was to break the magnetite structure in order to activate the Fe atoms and to acquire more $\mathrm{Fe}-\mathrm{OH}$ absorption sites for $\mathrm{As}(\mathrm{v})$ adsorption. ${ }^{53}$

Magnetic properties of $\mathrm{Fe}_{3} \mathrm{O}_{4}: \mathrm{S}$ NPs and $\mathrm{Fe}_{3} \mathrm{O}_{4}$ NPs are presented in Fig. 11. The saturation magnetization of $\mathrm{Fe}_{3} \mathrm{O}_{4} \mathrm{NPs}$ was $51.4 \mathrm{emu} \mathrm{g}^{-1}$, and the saturation magnetization of $\mathrm{Fe}_{3} \mathrm{O}_{4}: \mathrm{S}$ NPs before and after adsorption were $37.1 \mathrm{emu} \mathrm{g}^{-1}$ and 39.9
Table 4 Weight percentage of major components of $\mathrm{Fe}_{3} \mathrm{O}_{4}: \mathrm{S}$ before and after adsorption based on XRF analysis

\begin{tabular}{lllll}
\hline Sample & $\mathrm{Fe}$ & $\mathrm{O}$ & $\mathrm{S}$ & As \\
\hline $\mathrm{Fe}_{3} \mathrm{O}_{4}: \mathrm{S}$ & 64.98 & 33.23 & 1.78 & - \\
$\mathrm{Fe}_{3} \mathrm{O}_{4}: \mathrm{S}$ after adsorption & 63.66 & 33.29 & 0.24 & 2.79 \\
\hline
\end{tabular}

emu $\mathrm{g}^{-1}$ with an external magnetic field at $3 \mathrm{~T}$, respectively. The increase in saturation magnetization after adsorption might be attributed to the loss of sulfur during the adsorption process. Herein, $\mathrm{Fe}_{3} \mathrm{O}_{4}: \mathrm{S}$ NPs could be separated efficiently from aqueous solution after the adsorption of $\mathrm{As}(\mathrm{v})$ with an external magnetic field, which would be beneficial for their application. Separation experiments were conducted as shown in Fig. S1. $\dagger$ The adsorbent was dispersed in aqueous solution under continuous stirring. After adsorption, it took a long time for the adsorbent to precipitate naturally (Fig. S1(b) $\dagger$ ). However, the separation process of magnetic $\mathrm{Fe}_{3} \mathrm{O}_{4}: \mathrm{S}$ nanoparticles was conducted effectively within a few minutes with the help of an external magnetic field (Fig. S1(c) †).

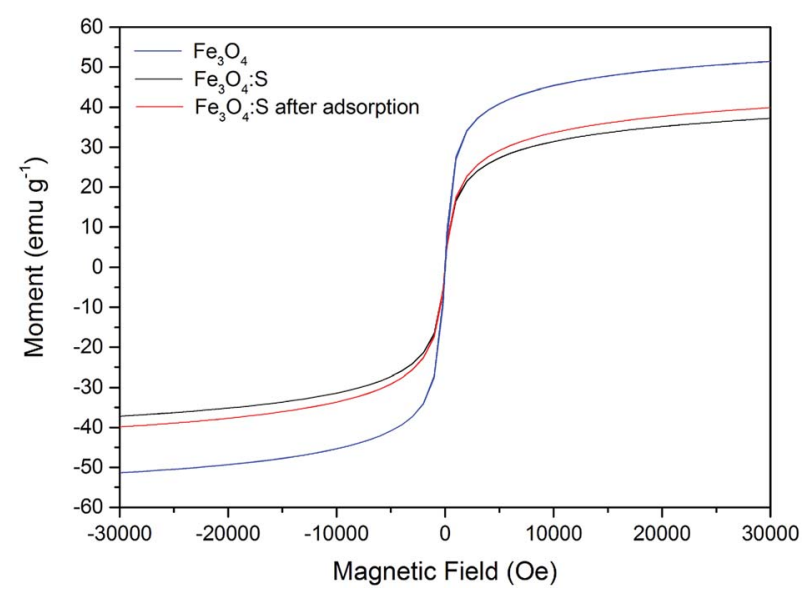

Fig. 11 Magnetization curves of $\mathrm{Fe}_{3} \mathrm{O}_{4}: \mathrm{S}$ before and after $\mathrm{As}(\mathrm{V})$ adsorption. Experimental conditions were the same as above.
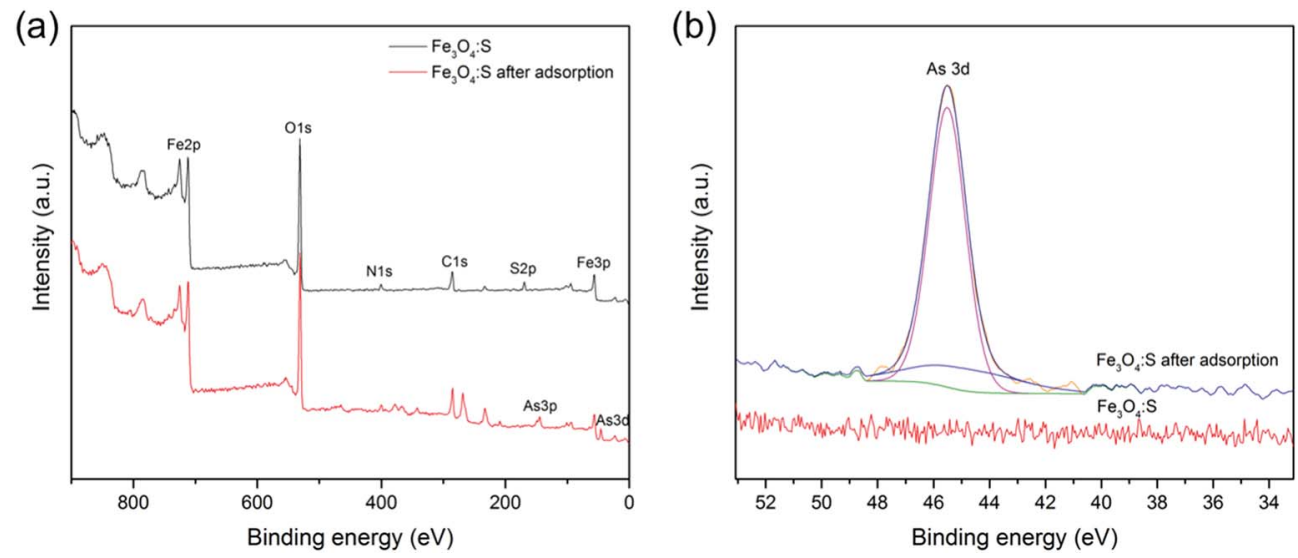

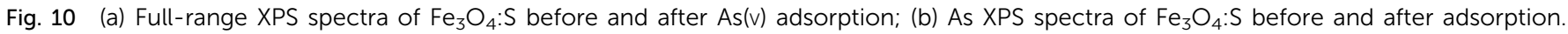
Experimental conditions were the same as above. 


\section{Conclusions}

An iron-based adsorbent, sulfur-doped $\mathrm{Fe}_{3} \mathrm{O}_{4}$ nanoparticles were prepared for the removal of $\mathrm{As}(\mathrm{v})$. Batch adsorption experiments indicated that the $\mathrm{Fe}_{3} \mathrm{O}_{4}: \mathrm{S}$ NPs show a highly efficient removal of $\mathrm{As}(\mathrm{v})$ compared with undoped $\mathrm{Fe}_{3} \mathrm{O}_{4}$ NPs. The pseudo-second-order kinetic model fitted well $\left(R^{2}=0.999\right)$ for $\operatorname{As}(v)$ adsorption. The Langmuir isotherm model was much more accurate $\left(R^{2}=0.990\right)$ than the Freundlich model in describing the As(v) adsorption process. XPS and FTIR spectra of $\mathrm{Fe}_{3} \mathrm{O}_{4}: \mathrm{S}$ NPs before and after adsorption proved that the adsorption of $\mathrm{As}(\mathrm{v})$ was through the $\mathrm{Fe}-\mathrm{OH}$ adsorption site, in which $\mathrm{As}(\mathrm{v})$ replaced the $-\mathrm{OH}$ group and formed stable $\mathrm{Fe}$ arsenates. The main role of sulfur doping was believed to affect the magnetite structure and activate the Fe atoms to acquire more $\mathrm{Fe}-\mathrm{OH}$ absorption sites. Besides, the adsorbent could be efficiently separated from the As(v) solution with an external magnetic field. Thus, $\mathrm{Fe}_{3} \mathrm{O}_{4}: \mathrm{S}$ NPs have considerable potential for $\mathrm{As}(\mathrm{v})$ adsorption in wastewater.

\section{Conflicts of interest}

There are no conflicts to declare.

\section{Acknowledgements}

This work is supported by the Major National Science and Technology Special Project of Water Pollution Control and Remediation (2017ZX07202) and National Natural Science Foundation of China (21773155).

\section{References}

1 B. K. Mandal and K. T. Suzuki, Talanta, 2002, 58, 201-235.

2 W. R. Cullen and K. J. Reimer, Chem. Rev., 1989, 89, 713-764.

3 P. Bhattacharya, A. H. Welch, K. G. Stollenwerk, M. J. McLaughlin, J. Bundschuh and G. Panaullah, Sci. Total Environ., 2007, 379, 109-120.

4 M. M. Hassan, Arsenic in Groundwater: Poisoning and Risk Assessment, Crc Press, 2018.

5 W. Ma, Y. Lin and Z. X. Feng, China J. Mod. Med., 2018, 13, 29-32.

6 S. Loewenberg, Lancet, 2016, 388, 2336-2337.

7 S. Kapaj, H. Peterson, K. Liber and P. Bhattacharya, Environ. Lett., 2006, 41, 2399-2428.

8 J. Q. Jiang, Water Sci. Technol., 2001, 44, 89-98.

9 J. M. Borgoño, P. Vicent, H. Venturíno and A. Infante, Environ. Health Perspect., 1977, 19, 103.

10 M. Berg, H. C. Tran, T. C. Nguyen, H. V. Pham, R. Schertenleib and W. Giger, Environ. Sci. Technol., 2001, 35, 2621-2626.

11 P. N. Williams, M. Lei, G. Sun, Q. Huang, Y. Lu, C. Deacon and Y. G. Zhu, Environ. Sci. Technol., 2009, 43, 637-642.

12 H. A. Michael, Science, 2013, 341, 852-853.

13 H. Guo, Y. Wang, G. M. Shpeizer and S. Yan, J. Environ. Sci. Health, Part A: Toxic/Hazard. Subst. Environ. Eng., 2003, 38, 2565-2580.
14 L. Zhang and C. Chen, J. Hyg. Res., 1997, 26, 310-313.

15 X. Guo, Z. Wu and M. He, Water Res., 2009, 43, 4327-4335.

16 L. Ruixia, G. Jinlong and T. Hongxiao, J. Colloid Interface Sci., 2002, 248, 268-274.

17 H. S. Altundoğan, S. Altundoğan, F. Tümen and M. Bildik, Waste Manag., 2002, 22, 357-363.

18 WHO, Guidelines for drinking-water quality. Volume 2: health criteria and other supporting information, 2nd edn, USA, 1996.

19 A. Audhya, M. Foti and S. D. Emr, Int. Conf. Mater. Renewable Energy Environ., 2011, 2, 1213-1216.

20 Y. Chammui, P. Sooksamiti, W. Naksata, S. Thiansem and O. A. Arqueropanyo, Chem. Eng. J., 2014, 240, 202-210.

21 USEPA, Technologies and Costs for Removal of Arsenic from Drinking Water, Books Llc, 2012.

22 Y. Meng, J. N. Wang, C. Cheng, X. Yang and A. M. Li, Chin. Chem. Lett., 2012, 23, 863-866.

23 S. Goldberg and C. T. Johnston, J. Colloid Interface Sci., 2001, 234, 204-216.

24 Y. Bai, T. Yang, J. Liang and J. Qu, Water Res., 2016, 98, 119127.

25 M. L. Pierce and C. B. Moore, Water Res., 1982, 16, 12471253.

26 L. Yan, S. Hu and C. Jing, J. Environ. Sci., 2016, 49, 74-85.

27 N. Horzum, M. M. Demir, M. Nairat and T. Shahwan, RSC Adv., 2013, 3, 7828-7837.

28 H. H. Li, W. F. Yan, Q. Liang, E. Zheng-yang and K. J. Ge, Nat., Environ. Pollut. Technol., 2017, 16, 627-632.

29 H. Genç-Fuhrman, J. C. Tjell and D. McConchie, Environ. Sci. Technol., 2004, 38, 2428-2434.

30 G. T. Burstein, Mineral. Mag., 1997, 61, 740-741.

31 T. H. Hsia, S. L. Lo, C. F. Lin and D. Y. Lee, Colloids Surf., A, 1994, 85, 1-7.

32 J. A. Muñoz, A. Gonzalo and M. Valiente, Environ. Sci. Technol., 2002, 36, 3405-3411.

33 X. Huang, L. Kong, S. Huang, M. Liu and L. Li, Sci. China: Chem., 2018, 61, 164-171.

34 Y. Zhang, M. Yang and X. Huang, Chemosphere, 2003, 51, 945-952.

35 L. Kong, L. Yan, Z. Qu, N. Yan and L. Li, J. Mater. Chem. A, 2015, 3, 15755-15763.

36 C. Ling, F. Q. Liu, C. Xu, T. P. Chen and A. M. Li, ACS Appl. Mater. Interfaces, 2013, 5, 11808-11817.

37 Y. S. Ho and G. McKay, Process Biochem., 1999, 34, 451-465. 38 Y. Li, Q. Du, X. Wang, P. Zhang, D. Wang, Z. Wang and Y. Xia, J. Hazard. Mater., 2010, 183, 583-589.

39 M. M. Motsa, B. B. Mamba, J. M. Thwala and T. A. Msagati, J. Colloid Interface Sci., 2011, 359, 210-219.

40 M. Dastkhoon, M. Ghaedi, A. Asfaram, A. Goudarzi, S. M. Langroodi, I. Tyagi and V. K. Gupta, Sep. Purif. Technol., 2015, 156, 780-788.

41 G. Mckay, H. S. Blair and J. R. Gardner, J. Appl. Polym. Sci., 1982, 27, 3043-3057.

42 A. S. K. Kumar and S. J. Jiang, J. Environ. Chem. Eng., 2016, 4, 1698-1713.

43 L. Feng, M. Cao, X. Ma, Y. Zhu and C. Hu, J. Hazard. Mater., 2012, 217, 439-446.

44 J. Lan, Res. Chem. Intermed., 2015, 41, 3531-3541. 
45 S. A. Baig, T. T. Sheng, C. Sun, X. Xue, L. Tan and X. Xu, PLoS One, 2014, 9, e100704.

46 S. A. Wasay, S. Tokunaga and S. W. Park, Sep. Sci. Technol., 1996, 31, 1501-1514.

47 SEPA, Emission standards of pollutants for secondary copper, aluminum, lead and zink industry (GB31574-2015), Beijing, 2015.

48 SEPA, Environmental quality standards for surface water (GB3838-2002), Beijing, 2002.

49 J. D. Russell, Clay Miner., 1979, 14, 109-114.
50 J. T. Keiser, C. W. Brown and R. H. Heidersbach, J. Electrochem. Soc., 1982, 129, 2686-2689.

$51 \mathrm{~K}$. Nakamoto, Infrared and Raman spectra of inorganic and coordination compounds, 1978.

52 S. Tokunaga, M. J. Haron, S. A. Wasay, K. F. Wong, K. Laosangthum and A. Uchiumi, Int. J. Environ. Stud., 1995, 48, 17-28.

53 Y. Zhang, M. Yang, X. M. Dou, H. He and D. S. Wang, Environ. Sci. Technol., 2005, 39, 7246-7253. 